\title{
Young People's Services in an Age of Neoliberalism
}

\author{
Graham Brotherton ${ }^{1}$, Christina Hyland ${ }^{1}$, Iain Jones ${ }^{1}$, Terry Potter $^{1}{ }^{*}$ \\ ${ }^{1}$ Newman University College, School of Human Sciences, Genners Lane, Bartley Green, B32 3NT Birmingham, United Kingdom
}

KEYWORDS

Young people

Youth services

Higher education

Neoliberalism

\begin{abstract}
This article brings together four different perspectives which explore the way in which various policy initiatives in recent years have sought to construct young people resident in the United Kingdom within particular policy discourses shaped by neoliberalism. In order to do this it firstly considers the way in which the assumptions of neoliberalism have increasingly been applied by the new Coalition Government to young people and the services provided for them; it then considers the particular role of New Labour in the UK in applying these ideas in practice. Specific examples from the areas of young people's participation in youth services and higher education policy are then considered .
\end{abstract}

\section{Youth Services under Threat: the Rise and Rise of Neoliberalism}

\begin{abstract}
'What is so troubling about the current historical moment is that youth no longer even symbolise the future. And yet, any discourse about the future has to begin with the issue of youth because more than any other group they embody the projected dreams, desires and commitments of a society's obligations to the future' (Giroux 2005: 85).
\end{abstract}

Henry Giroux sees the political ideology which has become known as 'neoliberalism' as a fundamental threat both to democracy and to ideas of community. He argues that the very environments and institutions in which young people learn to become politically conscious and engaged with their communities are closing down - not necessarily because they are

\footnotetext{
* Contact address: g.brotherton@newman.ac.uk (G. Brotherton)
} 
economically unviable or ineffective but because they are politically dangerous to the neoliberal discourse and its bid for hegemony.

Giroux, although writing from a U.S. perspective, is commenting on the global reach of this neoliberal political vision, characterised by Harvey (2005) as the embodiment of class action and dominance through the establishment of extreme pro-market capitalism.

'The State (...) must set up those military, defence, police, and legal structures and functions required to secure private property (...). Furthermore, if markets do not exist (...), they must be created, by State action if necessary.' (Harvey 2005: 2).

Both Giroux and Harvey would recognise the description by Naomi Klein (2007) of this political and economic strategy as 'disaster capitalism'. In her book The Shock Doctrine, Klein argues that the dominance of this particular incarnation of capitalism and its constant search for profit requires, at critical moments, a shock or disaster behind which it can shield its wider aspirations to transfer that which is collectively and publically owned (and used for the benefit of the widest number) into the hands of a private sector prepared to exploit those resources for wealth creation which benefits the minority.

'Believers of the shock doctrine are convinced that only great rupture (...) can generate the kind of vast, clean canvases they crave. It is these malleable moments, when we are psychologically unmoored and physically uprooted, that these artists of the real plunge in their hands and begin their work of remaking the world.' (Klein 2007: 21).

The recent financial and banking crisis that has gripped Western economies since $2007 / 8$ has provided just the level of intensity of financial and social shock needed to allow the capitalist class to use the 'crisis' as a pretext for a major assault on the idea of collectivism and solidarity as embodied in the concept of the welfare state - to the point where some are prepared to question whether the very concept of 'a State sector' has a future at all. Nowhere has this incursion of neoliberal thinking been more radically embraced than in the UK following the 2010 General Election. The coalition Government, forged from the majority Conservative Party and the minority 
Liberal Democrats, has built a political programme based on the concept of 'common austerity' in the economic realm as a necessary condition for the recovery from the earlier global banking collapse. Many commentators (Serwotka and Godrich 2010; Grover 2010; Taylor 2010), however, believe that the economic shock is in fact providing cover for an ideological assault on the concept of the 'big State'. Indeed, the Prime Minister, David Cameron, very explicitly acknowledges his desire to replace state provision with a combination of private sector, voluntary and philanthropic action he calls 'The Big Society' (http:/ / www.cabinetoffice.gov.uk).

Just as Giroux had outlined in the context of the United States, neoliberalism in Britain in 2010 also targets withdrawal of support and development aimed at young people as one of its key actions. Through the mechanism of public sector spending cuts, the current Coalition government has already launched a significant retrenchment in the resources available to support projects that focus on the diversity of youth development programmes in the public and voluntary sector and also those initiatives aimed at protecting vulnerable young people who might otherwise find themselves entering the criminal justice system. In July 2010 Joe Lepper from Children and Young People Now reported that:

'Dormant bank account assets will no longer be earmarked for young people's projects and will instead be used to fund the coalition government's broader Big Society agenda.' (Lepper 2010b).

Lepper (2010a) and his colleague, Lauren Higgs (2010) also reported on decisions by Lambeth Council to cut youth services by 35\% and on calls by the junior children's minister, Tim Loughton, for a complete review of local authority youth services. The National Council for Voluntary Youth Services (NCVYS) undertook research amongst their members in 2010 and concluded that :

'It is hardly surprisingly that almost $90 \%$ of the charities who responded think that the young people they work with will be adversely affected as a result of these cuts. They highlighted that young people will suffer from the loss of opportunities, support and advice available to them and also from the impact of less qualified staff working with them. In many cases, the young people 
they work with have complex needs and limited opportunities, and the loss of these services will be keenly felt. With 27 (20\%) of the respondents considering closure, and the vast majority of these (24) unable to suggest alternatives, it is likely that the outlook for young people will get worse.' (National Council for Voluntary Youth Services 2010: 2).

But it is significant that the Coalition government's rhetoric about the care and development of young people remains a prominent theme. So, if 'traditional' youth development and support services are being cut, what is moving in to take their place? The answer, The National Citizen Service, it would seem, fits the neoliberal political template perfectly, providing a programme that will mould young people into the 'decent' citizens of tomorrow. This idea was captured by the Prime Minister in his document It's time to inspire Britain's teenagers: National Citizen Service for the 21st century (2010):

'My vision would harness the talents, commitments and energies of our young people by making their seventeenth year the bridge between their teenage life and young adulthood, a time for them to develop as individuals by putting something back into society.' (Cameron 2010).

We started this contribution by referencing Giroux's view that neoliberalism as a political philosophy probematises many young people and seeks to neutralise their perceived threat to the status quo by limiting the public space, public resources and institutions open to them. We further argue that the current British government, using the cover of economic disaster, has moved to implement a radical neoliberal agenda in the UK and that this is also characterised by an attack on the young and the services and projects that serve them. In place of projects young people have ownership of the Government are seeking to implement a programme of youth engagement that serves their own ends. A programme that manages their 'transition' from the world of the dependent child to the world of the compliant adult. These will be the adults who exemplify and promote the Government's aspiration for a small state and a Big Society - a place where the possibility of resistance, dissent and individual development is replaced by conformity and compliance to government-led agendas. 


\section{New Labour, Neoliberalism and Young People}

Policy around youth in the United Kingdom in recent years has been predicated on two key assumptions both of which it can be argued are framed by neoliberal discourses: firstly the growth of a view of young people as 'human capital' who need to be developed for an increasingly flexible and uncertain labour market; key to achieving this is the requirement that they are engaged in 'purposeful' activity. A second key assumption is that they are simultaneously both in danger and dangerous and hence that wider society needs to both protect and be protected from young people (Wyness 2006).

Turning first to the question of young people as potential. In the wake of the New Labour victory in the 1997 general election, the work of the sociologist Anthony Giddens became increasingly influential in the formulation of policy. Giddens even co-authored a book with the then British Prime Minister Tony Blair. For our purposes the significance of this relationship lies in the explicit acceptance of Giddens's formulation of the relationship between the individual and the state in late-modern societies which emphasises the state as springboard rather than safety net.

For Giddens one of the defining features of late modernity is its emphasis on what he calls life politics -that is an emphasis on the politics of individual identity, rather than on emancipatory politics with its emphasis on broader social equality, justice and participation. This he suggests is in itself linked to the decline in support for traditional social democratic solutions and the acceptance by at least parts of the European and US 'left' of the reality of globalisation and the need to accommodate 'market solutions' (Giddens 2002). As Elliott (2009) suggests in summarising Giddens:

'How people think about monitor and reflect on what they do (...) is crucial to how society constitutes itself. In our own age however there this is a radical intensification of reflexivity such that selfmonitoring and social relations become increasingly interwoven.' (Elliott 2009: 132). 
Layder (1997) in critiquing Giddens suggests, that in rejecting objectivism in sociological analysis Giddens underestimates the extent to which predetermined power relations play a role in interactions between individuals and institutions. This may be of central importance in the translation of a sophisticated model of sociological analysis into the realm of political prescription, in that it can be argued that it leads to an underestimation of the power inherent in the relationship between providers of services, in this case for young people and those young people who use the services. Conversely it may also lead to an overestimation of the capacity of young people to construct and reconstruct themselves reflexively through their contact with institutions such as schools, universities or youth services.

To give a specific example which will be developed later Davies (2009) traces the way in which in the UK the notion of youth work with its emphasis on informal young-person lead approaches, has increasingly been absorbed into generic youth services which emphasise child protection or youth justice rather than informal education or youth led provision. It is our contention that this shift is constituted in practice as a debate about reflexivity as a form of self policing within the context of neo-liberal discourses. In particular there has been a move to see young people in terms of their economic potential which the state has a key role in 'freeing,' in the green paper 'Youth Matters' published in 2005 this is a dominant theme. This discourse of purposefulness as being central to effective Youth Policy recurs frequently:

'We want a system in which young people have a clear expectation of the support and opportunities available to them, but also a clear understanding that these benefits are not unconditional - young people also have responsibilities.' (Youth Matters 2005: 22).

However at the same time there has been a discourse characterised by a number of writers for example Garrett (2007) and Grover (2010) as either the rediscovery of the 'undeserving poor' as a category requiring social intervention or as the growth of 'vindictiveness' in social policy in which the state seeks to identify and 'punish' those who are perceived as not discharging their social obligations. Grover (2010) gives examples in respect of Housing Benefit and Treatment Allowances for drug users becoming 194 
increasingly conditional on the avoidance of perceived anti-social behaviour and a number of recent announcements around work related benefits (Duncan-Smith 2010) could be said to fall into this category.

The consequence of this two pronged approach has been an extension in the surveillance of the state into young people's lives characterised on one hand by the 'Every Child Matters 'agenda with its at least rhetorical focus on supportive intervention and on the other hand by a range of criminal justice focused initiatives such as the 'Respect Action Plan'. This in turn can be said to link to a more 'normative view' of young people's behaviour expressed through policy which in itself links back to neo-liberal discourses as highlighted previously.

Since the formation of the Conservative/Liberal Democrat coalition government in 2010, the major explicit policy initiative aimed at young people has been the decision to propose much higher levels of tuition fee for access to higher education. A decision which has in itself lead to a series of high profile protests lead by young people themselves. Other significant initiatives are subsumed into other policy areas, such as benefit reform as highlighted previously. However, despite some change of language, the evidence such as it is points to further intensification of the neoliberal approach. In the next two sections we seek to look at two particular manifestations of the discourse in policy and practice.

\section{Tipping the Balances of Power - or Managing Compliance?}

UK public policy has expressed a theoretical interest in young people's participation since the late 1960's, with government beginning to acknowledge calls for a stronger voice for children and young people throughout the 1970's and 1980's (Carnegie Young People Initiative 2008). The UK ratified the UN Convention of the Rights of the Child in 1991 (but it is still not enshrined in UK legislation) and in doing so appeared to acknowledge the right of young people to have their views given due weight in the decisions affecting their lives. Between 2001 and 2005, Children's Commissioners were appointed in each of the four UK countries ostensibly to ensure that the UNCRC is implemented, and a plethora of 
policies made an explicit commitment to ensuring the participation of children and young people in development of services and decision making.

However, the Carnegie Young People Initiative (2008) suggests that young people are still alienated from decisions that affect their lives and that we have yet to experience a sustained cultural or attitudinal shift, with organisations operating in a culture of 'compliance' rather than looking to extend sustained change. Milbourne (2009) highlights 'institutional resistance' with policies and strategies tending to emphasise inclusion rather than institutional change, focusing on the perceived deficiencies of young people rather than the need for systemic change in the services that exclude them. Hill et al. (2004) similarly argue that children and young people are largely treated as passive recipients and consumers of services, with policy makers operating with a deficit model of young people, so that, despite an alleged plethora of consultations and participatory mechanisms, the voices of young people still have little or no impact on local and national policy making.

Milbourne (2009) asks the question 'whose reality counts?' and clearly identifies that a 'top down' approach of target setting, short term funding, structured activities and an 'assimiliation' of young people which 'ticks the boxes' and secures compliance is prevailing and is in direct contrast to a 'bottom up' approach which engages with the tensions of participatory practice in enabling young people to present their own ideas, potentially challenging existing institutions and structures and professional concepts of power. Policy drivers around participation which have been increasingly rooted in deficit models of young people, focussing on perceptions of young people failing to live up to adult expectations, are contrary to the Youth Services' traditional commitment to seeing participation as a way of enabling young people to be active in challenging power differentials, shaping their own lives and the world around them, and creating spaces where critical thinking and action can thrive (Wood 2010).

However, Coburn (2008) argues the power imbalance between adults and young people negates young people's rights to participation, association and critical thinking or action, while the state dilutes the Youth Service through policy development and lack of support to a point where youth workers are immobilised. Taylor (undated) forcefully suggests that youth 
workers no longer have any power in determining the purpose and content of their work, largely doing as they are told, while young people have no power in arguing their own case for their needs either with youth workers or the state. Mitzen (2010) similarly argues that youth workers' freedom to use their professional judgement, and to determine agendas with young people, has been wiped out by the (relentless) push towards risk assessments, pre-determined target driven outcomes, (funding hoops) and the effects of competitive tendering and privatisation, thus drawing youth workers in to exercises of control and direction and limiting the spaces for working with young people on the agendas and needs that they expressly articulate. Approaches to youth work that some might consider to be 'radical' - that is, approaches that include emphasis on the exploitative nature of capitalism, recognise the structural role in equalities, accentuate the need for 'consciousness raising' and acknowledge young people as agents of change (Hurley \& Treacy, in Ord 2007) are, it seems, being eroded. Much of what operates under the label of youth work, and the participation agenda, has been moved away from its potentially liberating role as an emancipatory, democratic educational process and is instead being driven as a route to implement a market- driven state agenda of compliance and surveillance that is controlled through Government funding routes.

The 'In Defence of Youth Work' Campaign which was launched in March 2009 challenges what they describe as the pressure to become 'agencies of behaviour modification' and aims to 'defend a democratic and emancipatory youth work' with its cornerstones including:

- An insistence upon a democratic practice within which every effort is made to ensure that young people play the fullest part in making decisions about anything affecting them.

- A commitment to conversations with young people which start from their concerns and within which both youth worker and young person are educated and out of which opportunities for new learning and experience can be created.

- A commitment to valuing and attending to the here-and -now of young people's experience rather than just focusing on 'transitions'.' (In Defence of Youth Work)

Children \& Young People Now has, since the election of the coalition Government, launched the 'For Youth's Sake' campaign which has three 
initial priorities:

- The first calls on the government to set out its vision for young people.

- The second, asks for young people to have a genuine say on a local and national level in shaping the services that affect them and calls for them to be given powers to decide where money is spent in their communities.

- The third, calls on employers to invest in the youth workforce to ensure young people are provided with the best possible support from properly trained staff and volunteers and for those who work with young people to feel valued for the vital role they play in their communities. (For Youth's Sake 2010)

So, after decades of rhetoric around young people's participation, and as we receive weekly reports of the coalition governments cuts in services and funding that amount to the decimation of local youth services and voluntary youth organisations, learn that the role of the Children's Commissioner for England is 'under review', and struggle with a vision of a 'Big Society' that reduces state responsibilities to its citizens, we would do well to remind ourselves that youth work in the UK has traditionally made an explicit commitment to tipping the balances of power in young people's favour, and that this should not be an optional extra but should be reasserted without compromise (Davies 2005).

\section{Transitions: Identity, pedagogy and place}

The earlier themes of the article relate to resistance or compliance in youth work and of balances of power and policy shifts in working with young people. The following section analyses how policy discourses, or 'big policies' operating in a 'small world' (Alexiadou and Jones 2001), are interpreted and enacted by learners within 'local spaces' in higher education. These spatial dimensions are one of the ways of seeing, understanding and working on discourses of widening participation, within higher education, and of how these discourses are mediated by and within specific local educational settings and processes. Whilst sharing the concerns of other contributors to this article, about the presence of a dominant neoliberal discourse and of an absence beyond a rhetorical commitment to the 198 
participation of young people in services and decision making, Ball's argument is key:

'Policies are contested, interpreted and enacted in a variety of arenas of practice and the rhetorics, texts and meanings of policy makers do not always translate directly and obviously into institutional practices. They are inflected, mediated, resisted and misunderstood... It is important not to overestimate the logical rationality of policy.' (Ball 2008: 7).

Research on the voices of learners in higher education can be designed to trouble the concept of 'transition'. Tracing the interplays between identity, pedagogy and place can be used to develop a more nuanced sense of how policy is inflected and mediated by such voices.

Dominant contemporary policy discourses position widening participation and transition through a student lifecycle of stages and milestones and of the need for the monitoring and measurement of success (HEFCE 2001; HEFCE 2009). National policy texts emphasise a deficit model and rational strategic approach to widening participation as critiqued by, for example, Thomas and Jones (2005) and Greenbank (2006). Individual and shared experiences, including those of learning within specific settings, suggest both complex and situated processes that disrupt the 'derogatory discourses' of widening participation that Burke (2009) critiques. The interplays between individual and shared experiences of learning and institutional representations of policy suggest that policy is both complex and situated and as Ozga (2000: 42) argues 'involving negotiation, contestation and a struggle between competing groups, as a process rather than output'. The emerging themes of research reported by Jones (2010) related to the interplay between the students' diverse experiences and different dimensions of affinity that may suggest one way of looking at a transformative approach to widening participation (Jones and Thomas 2005) as an alternative to a 'derogatory discourse' (Burke 2009). As they argue, in defining their meaning of transformative education:

'Rather than being predicated on deficit models of potential entrants and positioning students as lacking aspirations, information or academic preparation, transformation requires serious and far-reaching structural change... which is to be 
informed by under-represented groups (Jones and Thomas 2005: 619).

The students in Jones' preliminary study (2010) contrasted the objective form of their experience, as measured by status or position and represented by a formal event, (for example, movement from FE to HE level 4 or HE level $4-5$ ), with its subjective dimension as understood through the meanings given to those situations. Their accounts disrupted the discourse of the rational model of widening participation and, as Merrill and Crossan (2000) argue, the benefits of life history research are that:

'Meaning is given to life experiences. Using biographical approaches enabled the voices of participants to be heard, placing them central to the research process as they reflected upon, interpreted, gave meaning to and constructed past events and experiences within a social context.' (Merrill and Crossan 2000: 2).

The examples drawn from the initial focus groups, in the preliminary research, suggested the complexity of the meanings that students attributed to their experiences and that their experiences of transition were not 'smooth'. Focus groups were not used to minimize uncertainty but to explore the contradictions within and between participants shared accounts. These meanings also need to be read in understanding the discourses of widening participation. Further research will contribute to ways of conceptualising transition that goes beyond an essentialist representation of the student lifecycle using the sensitising concepts of identity, place and pedagogy.

In theorising learners transitions between FE and $\mathrm{HE}$, and within $\mathrm{HE}$, different contributions to work on the concept of dialogic learning are significant including the work of Freire (1970) on dialogic action, Flecha (2000) on dialogic learning, dialogic instruction (Nystrand 1997), dialogic inquiry (Wells 1999), dialogic teaching (Alexander 2004; Wolfe and Alexander 2008) and dialogical pedagogy (Skidmore, 2000; Skidmore and Gallagher 2005). Whilst the majority of these derived from, and have been applied to, primary and secondary education they offer potential as methodological tools for studying and understanding learners experiences of identity, place and pedagogy in transitions between and within further and higher education. Skidmore and Gallagher (2005: 1) argue that: 
'With the emphasis on offering students the opportunity to construct meaning in their own words, there is an affinity between these dialogic conceptions of pedagogy and the constructivist approach to education. From a constructivist perspective, learning does not take place apart from the active intellectual, moral, and social engagement of the learner. To recognize this point is to acknowledge the essentially transactional nature of teaching and learning: teaching is not a unidirectional act, something teachers do to students; rather, constructivist theory implies the need for a democratisation of the traditional power relationships between teachers and students, built on a view of students as intellectually autonomous meaning-makers.'

Further research will be developed and refined where the development of the curriculum and forms of pedagogy are informed by dialogue, meaning making and the co-construction of knowledge between lecturers and cohorts of students (through methods including focus groups and classroom observation) but also by students as researchers. The initial evidence from the preliminary research reported in Jones (2010) will contribute to the development of research, and further investigation of the following emerging issues, in relation to identity, pedagogy and place: the debate over students 'fitting in' to the institution; the curriculum and forms of pedagogy adapting to a variety of needs of the students; and potential for the curriculum and forms of pedagogy being informed by the students. Emerging findings suggested that students have multiple not singular identities and it is imperative to develop methods that can identify the combinations and shifts in these. The investigation of this research problem will build on the work of Jones and Thomas (2005), Greenbank (2006), Burke (2009), Merrill and Crossan (2000), and Lynch and Field (2007) but combine this literature, that has focussed on further and higher education in England and Scotland, with literature on dialogic learning which has largely been concerned with research on primary and secondary education in the UK and North America or adult education and its initial applications in Spain and Latin America. By combining policy analysis and dialogic learning, further research will seek to disrupt the 'derogatory discourses' of widening participation (Burke 2009) and problematise the notion of transition as being about a series of events which have 'the effect of flattening life trajectories in 
order that they become more measurable and controllable' (Lynch and Field 2007: 10).

\section{Conclusion}

In this paper we have sought to suggest that three decades of policy dominated by neoliberal discourses have had significant negative effects on the lives of young people through constructing the process of 'growing up' and the transitions associated with it, in a way which is held together by notions of economic potential, 'marketised' notions of choice and increased surveillance.

The task for those involved in services that work with young people or for those seeking to evaluate them, is to find a way of responding to this. We started with the critique of neoliberalism developed by Giroux; in developing his critique Giroux makes extensive use of the work of Zygmunt Bauman who suggests that one of the triumphs of neoliberalism has been its ability to privatise public space economically, physically and intellectually. A quote from Bauman also used by Giroux is helpful here:

'Democracy is not an institution, but essentially an anti-institutional force, a rupture in the otherwise relentless trend of the powers that be to arrest, change silence and eliminate from the political process all those who have not been 'born' into power (...) democracy is an anarchic disruptive element within the political system, a force for dissent and change.' (Bauman 2001: 54).

There is a long tradition in work with young people of seeking to work in ways which actively promote Bauman's notion of democracy that is now in danger of being marginalised or extinguished. We illustrate this with two specific examples which are relevant to this paper.

Firstly, within youth work there is a long and distinguished tradition of work which actively seeks to build partnerships with young people in non directive ways and which finds it increasingly difficult to obtain funding in the context of the 'target driven' approach which has become a feature of the service provider environment. Very often access to money is contingent on achieving outputs pre-determined and commissioned by funding agents - whether statutory or charitable - and providing evidence 
that activities that cannot easily be measured are worth doing becomes ever harder.

Secondly, the still rather limited tradition in recent years of seeking to 'widen participation' in ways which avoids reproducing a deficit model of young people from 'non-traditional' backgrounds is now threatened by funding cuts in higher education in the UK. The Coalition Government, having accepted an essentially market-led model of university funding is seeking to impose tuition fees of up to $£ 9000$ per year on new students, whilst reducing support through grant support to those institutions which have done most to broaden the range of students who are able to access higher education (Million+2010).

Whilst not wishing to sound either naively optimistic or merely fatuous, resisting the relentless tide of neoliberalism requires us to engage with young people in ways which are consonant with Bauman's notion of democratic practice and in this way create space for alternative reflexive constructions of identity.

\section{References}

Alexander, Robin J. 2004. Towards Dialogic Teaching: Rethinking Classroom Talk. York: Dialogos.

Alexiadou, Nafsika and Ken Jones. 2001. Travelling Policy/Local Spaces. Paper presented at Congrès Marx International III: Le capital et l'humanité, September 26-29, Nanterre-Sorbonne: Université de Paris-X.

Bauman, Zygmunt. 2001. The Individualised Society. London: Polity.

Burke, Penny Jane. 2009. Reconceptualising Widening Participation. Paper presented at NALN Annual Conference, February 11-12, London: British Academy of Film and Television Arts.

Cameron, David. 2010. It's Time to Inspire Britain's Teenagers: National Citizen Service for the 21 $1^{\text {st }}$ Century. London: Conservative Party.

Carnegie Young People Initiative. 2008. Empowering Young People: The Final Report of the Carnegie Young People Initiative. Dunfermline: Carnegie UK Trust.

http://cypi.carnegieuktrust.org.uk/files/cypi_final_report_0.pdf (accessed September 9, 2009).

Coburn, Annette. 2008. Policy, Politics and Practice: Work with Young People. In The Edinburgh Papers. Reclaiming Social Purpose in Community Education, 22-24. Available online at: 
http:/ / www.critically-chatting.0catch.com/recentarticles/index.html\#bv000003 (accessed September 7, 2010).

Davies, Bernard. 2009. Defined by History: Youth Work in the UK. In The History of Youth Work in Europe and Its Relevance for Youth Policy Today, eds. Griet Verschelden; Filip Coussée; Tineke Van de Valle and Howard Willimson, 56-77. Strasbourg: Council of Europe Publishing.

Davies, Bernard. 2005. Youth Work: A Manifesto for Our Times. Youth $\mathcal{E}$ Policy 88: 5-28.

Flecha, Ram-n. 2000. Sharing Words.Theory and Practice of Dialogic Learning. Lanham: Rowman \& Littlefield.

Freire, Paolo. 1970. Pedagogy of the Oppressed. New York: Continuum Books.

Giddens, Anthony. 2002. Where Now for New Labour?. London: Fabian Society.

Giroux, Henry A. 2005. The Terror of Neoliberalism. London: Paradigm.

Greenbank, Paul. 2006. The Evolution of Government Policy on Widening Participation. Higher Education Quarterly 60 (2): 141-166.

Grover, Chris. 2010. Social Security Policy and Vindictiveness. Sociological Research Online 15, www.socresonline.org.uk/15/2/8.html (accessed November 3, 2010).

Harvey, David. 2005. A Brief History of Neoliberalism. Oxford: Oxford University Press.

Harvey, Lee and Sue Drew, with Maria Smith. 2006. The First-Year Experience: A Review of Literature for the Higher Education Academy. York: Higher Education Academy.

HEFCE. 2009. Request for Widening Participation Strategic Assessments. Bristol: Higher Education Funding Council for England, January.

HEFCE. 2001. Strategies for Widening Participation in Higher Education. Bristol: Higher Education Funding Council for England, Guide 01/36.

Higgs, Lauren. 2010. Loughton Calls for Overhaul of Local Authority Youth Services. Children \& Young People Now, July 8.

Hill, Malcolm, John Davis, Alan Prout and Kay Tisdall. 2006. Moving the Participation Agenda Forward. Children \& Society 18 (2): 77-96.

Jones, Iain. 2010. Senses of Belonging and Fitting in? Affinities and Emergent Identities. Widening Participation and Lifelong Learning 12 (2): 23-35.

Jones, Robert and Liz Thomas. 2005. The 2003 UK Government Higher Education White Paper: A Critical Assessment of Its Implications for the Access and Widening Participation Agenda. Journal of Education Policy 20 (5): 615-630.

Klein, Naomi. 2007. The Shock Doctrine: the Rise of Disaster Capitalism. London: Allen Lane.

Kirby, Perpetua and Sara Bryson. 2002. Measuring the Magic? Evaluating and Researching Young People's Participation in Public Decision Making. London: Carnegie Young People Initiative. 
Layder, Derek. 1997. Modern Social Theory. London: UCL Press.

Lepper, Joe. 2010a. Lambeth Council Could Cut Funding for Youth Charities by 35 per cent. Children \& Young People Now, July 23.

Lepper, Joe. 2010b. Youth Projects Lose Out on Dormant Bank Account Funds. Children \& Young People Now, July 19.

Lynch, Heather and John Field. 2007. Getting Stuck, Becoming Unstuck: Transitions and Blockages between Learning Contexts. Paper presented at the 'Transitions and Learning in the Life Course: Insights from the Learning Lives' Project Symposium, CRLL Conference, June 22-24, Stirling, UK.

Mannion, Greg. 2007. Going Spatial, Going Relational: Why "Listening to Children" and Children's Participation Needs Reframing. Discourse: Studies in the Cultural Politics of Education 28 (3): 405-420.

Merrill, Barbara and Beth Crossan. 2000. Life Stories and Learning: the Role of Gender in Influencing Participation and Non-participation in Further Education in Scotland, Paper presented at ESREA Biography Network Conference on Gender, Learning and Biography, March 1619, Roskilde, Denmark.

Milbourne, Linda. 2009. Valuing Difference or Securing Compliance? Working to Involve Young People in Community Settings. Children $\mathcal{E}$ Society 23 (5): 347-363.

Million+. 2010. Fair Progressive and Good Value.

http://www.millionplus.ac.uk/research/index

Mitzen, Phil. 2010. Working in Welfare. Youth Policy's Contradictions and Dilemmas. In Ethical Issues in Youth Work, ed. Sarah Banks, 24-37. Abingdon: Routledge.

National Council for Voluntary Youth Services. 2010. Comprehensive Cuts Facing the Voluntary and Community Youth Sector.

http:/ / www.ncvys.org.uk/blogs.php?act=view_topic\&id=185

(October 12, 2010).

Ord, Jon. 2007. Youth Work Process, Product and Practice: Creating an Authentic Curriculum in Work with Young People. Lyme Regis: Russell House Publishing.

Ozga, Jenny. 2000. Policy Research in Educational Settings, Buckingham: Open University Press.

Serwotka, Mark and Janice Godrich. 2010. There Is An Alternative: the Case Against Cuts in Public Spending. London: Public and Commercial Services Union.

Skidmore, David. 2000. From Pedagogical Dialogue to Dialogical Pedagogy. Language and Education 14 (4): 283-296.

Skidmore, David and Deborah J. Gallagher. 2005. A Dialogical Pedagogy for Inclusive Education. Paper presented at Inclusive and Supportive Education Congress, August 1-4, Glasgow, UK.

Taylor, Robert. 2010. Welfare to Worklessness. Red Pepper 173: 14-15. 
Taylor, Tony. Undated. Youth Work \& Class: The Struggle That Dare Not Speak Its Name. Available online at:

http://www.critically-chatting.0catch.com/recentarticles/index.html\#bv000003 (accessed September 7, 2010).

Wells, C. Gordon. 1999. Dialogic Inquiry: Towards a Sociocultural Practice and Theory of Education. Cambridge: Cambridge University Press.

Wood, Jason. 2010. Young People as Activists. Ethical Issues in Promoting and Supporting Active Citizenship. In Ethical Issues in Youth Work, ed. Sarah Banks, 192-206. Abingdon: Routledge.

Wolfe, Sylvia with Robin J. Alexander. 2008. Argumentation and Dialogic Teaching: Alternative Pedagogies for a Changing World. London: Beyond Current Horizons, Futurelab.

* **. 2010. For Youth's Sake. Children \& Young People Now. http://www.cypnow.co.uk/BigIssues/Details/85890/for-youths-sake/ (accessed November 15, 2010).

***. 2010. Building the Big Society. Cabinet Office website: http://www.cabinetoffice.gov.uk/media/407789/building-big-society.pdf (accessed November 21, 2010).

***. 2005. Youth Matters. Department for Education website: http://www.education.gov.uk/consultations/downloadableDocs/ Youth\%20mattters\%20pdf.pdf (accessed November 21, 2010).

***. Undated. In Defence of Youh Work. What We Stand for. http:// www.indefenceofyouthwork.org.uk/wordpress/?page_id=2 (accessed November 21, 2010). 